\title{
PENGARUH IKLAN DAN KUALITAS PRODUK TERHADAP KEPUTUSAN PEMBELIAN STUDI KASUS PADA CV CEMILAN KUNIK GARUT
}

\author{
Oleh: \\ Hari Mulia \\ STIE Yasa Anggana Garut \\ Email : muliahari0@gmail.com
}

\section{Linda Risnawati}

\begin{tabular}{l}
\hline Article Info \\
\hline Article History : \\
Received 23 July - 2020 \\
Accepted 20 August - 2020 \\
Available Online \\
07 Sept - 2020
\end{tabular}

Keyword :

Advertising, Product

Quality And Purchase

Decisions.

\begin{abstract}
The purpose of this research is to know about advertising, product quality and purchase decisions on CV finger Kunik Garut and to know the effect of advertising on purchasing decisions, the influence of product quality on purchasing decisions, and the influence of advertising and product quality to purchase decisions on food product CV snack Kunik Garut. The research method used is a descriptive method. A descriptive method of research is done to know the value of a self-variable, either one or more variables (independent) without making comparisons, or linking between variables one to another. The population in this research is all consumers who have ever made a purchase of products on food product CV snack Kunik Garut, while samples were taken amounting to 68 people and sample withdrawal is done using incidental sampling. Based on data processing using SPSS Veri 20 , the research instrument used in the study was declared valid because it has a greater value of the $R$ table of 0.238 and is reliable because it has a greater value of the Cronbach alpha value of 0.600. From AD correlation test results have a strong influence on purchasing decision with $R$ value of 0.646 and coefficient of determination of $41.3 \%$ and the remaining $58.7 \%$ are influenced by other factors that are not researched, while the test result of product quality correlation has strong influence on purchasing decision with $R$ value of 0.634 and coefficient of determination of $43.3 \%$ and remaining $56.7 \%$ influenced by other factors that are not researched. Then the test results of ad correlation and product quality have a very strong influence on purchasing decisions with a $R$ value of 0.824 and a coefficient of determination of $67.9 \%$ and the remaining $32.1 \%$ are influenced by other factors not researched.
\end{abstract}




\section{PENDAHULUAN}

Pertumbuhan dunia usaha makanan online dewasa ini semakin meluas. Pesatnya pertumbuhan ekonomi yang didukung dengan perkembangan teknologi membawa kepada persaingan yang semakin ketat dalam usaha makanan online. Keadaan ini menjadikan iklan dan kualitas produk menjadi kunci bagi suatu perusahaan untuk memenangkan persaingan dalam menciptakan kepuasan para konsumen terhadap keputusan pembelian. Iklan merupakan salah satu peranan penting bagi perusahaan begitu juga dengan kualitas produk perusahaan. Karena persaingan terus meningkat, produkproduk usaha makanan online bersaing dengan promosi mengkomunikasikan keunggulan produk-produk makanan online masing-masing perusahaan sehingga memberikan kemudahan calon pembeli untuk memilih produk sesuai kebutuhan dan keinginan calon pembeli tersebut.

Sesuai dengan UU Perlindungan Konsumen Nomor 8 Tahun 1999 Tentang Perlindungan Konsumen Republik Indonesia menjelaskan bahwa hak konsumen diantaranya adalah hak atas kenyamanan, keamanan, dan keselamatan dalam mengonsumsi barang dan atau jasa, hak untuk memilih barang dan atau jasa serta mendapatkan barang dan atau jasa tersebut sesuai dengan nilai tukar dan kondisi serta jaminan yang dijanjikan, hak untuk diperlakukan atau dilayani secara benar dan jujur serta tidak diskriminatif, hak untuk mendapatkan kompensasi, ganti rugi dan atau penggantian, apabila barang dan atau jasa yang diterima tidak sesuai dengan perjanjian atau tidak sebagaimana mestinya dan sebagainya. Maka dari itu, setiap perusahaan harus bisa menyusun dan mendesain suatu strategi pemasaran yang baik dalam perkembangan diera globalisasi saat ini yang nantinya mampu mendukung usahanya.

Persaingan dalam perkembangan diera globalisasi menuntut perusahaan harus mampu bersikap dan bertindak cepat serta tepat dalam menghadapi persaingan di lingkungan bisnis yang bergerak sangat dinamis yang penuh dengan ketidakpastian. Kebutuhan masyarakat akan makanan menimbulkan adanya persaingan antar usaha makanan online lainnya untuk dapat menarik minat pangsa pasar agar mau membeli produk yang dijual, persaingan timbul dan para usaha makanan online mulai bersaing baik dari segi iklan maupun segi kualitas produk unggulan perusahaan masing-masing. Sehingga masyarakat merasa puas atas produk yang telah dibeli.
Perusahaan dalam mempertahankan kemampuannya, diharuskan menjaga dan meningkatkan kualitas produknya, kualitas produk merupakan kemampuan produk untuk memuaskan kebutuhan atau keinginan konsumen. Agar perusahaan berkembang dan keuntungan bisa diraih, maka perusahaan harus menjaga kualitas produksinya, hal ini menandakan bahwa kualitas produk sangat mempengaruhi konsumen, produk yang memilki kualitas baik, handal dan memiliki karakteristik yang berbeda dari yang lainnya serta sesuai dengan yang diharapkan konsumen, maka tentunya akan meningkatkan minat konsumen untuk melakukan pembelian.

Suatu produk yang dihasilkan tidak hanya diharuskan memiliki kualitas yang baik, tetapi juga diperlukan suatu media pemasaran yang tepat agar produk bisa sampai pada konsumen. Salah satu bauran pemasaran yang bisa dilakukan agar dapat menjaga pelanggan tetap setia dan menarik konsumen yang akan datang, yaitu melalui promosi iklan. Iklan dimaksudkan untuk mempromosikan gagasan, barang, jasa atau mempengaruhi konsumen dalam bentuk tulisan, gambar atau film. Oleh karena itu iklan merupakan promosi yang paling penting dan sering digunakan. Hal ini disebabkan karena dengan beriklan maka produk menjadi lebih terkenal di masyarakat, lebih efektif, dan luasnya jangkauan yang dapat diraih.

Konsumen memiliki preferensi terhadap suatu produk sehingga nantinya akan mempengaruhi keputusan pembelian. Keputusan pembelian adalah suatu proses pemilihan salah satu dari berbagai alternatif sesuai dengan preferensi. Keterlibatan konsumen dalam suatu pembelian produk ditentukan oleh stimulus (rangsangan), apakah seseorang merasa terlibat atau tidak terhadap suatu produk ditentukan oleh apakah konsumen merasa dirinya penting atau tidak dalam keputusan pembelian produk atau jasa. Dengan demikian, bisa dikatakan ada konsumen yang memiliki keterlibatan rendah terhadap pembelian produk barang atau jasa.

Pengambilan keputusan yang dilakukan oleh konsumen sangat beragam dan tidak sama antara satu dengan yang lainnya sesuai dengan kebutuhan, keinginan, selera, dan berbagai faktor yang mempengaruhi konsumen itu sendiri. Keputusan pembelian dapat berubah seiring berjalannya waktu dan kondisi dari diri konsumen tersebut yang mempengaruhi kegiatan pembelian suatu produk. Perusahaan diharapkan dapat mengikuti perubahan dan selera konsumen yang berubah-ubah. Hal yang 
bisa dilakukan oleh perusahaan adalah dapat memberikan kepuasan bagi konsumen seperti dalam penanyangan iklan sesuai bahkan kualitas. Seperti pendapat menurut Kotler dan Amstrong (2012 : 212) mengatakan bahwa "Pemasar yang memperhatikan kualitas bahkan diperkuat dengan periklanan dan harga yang wajar maka konsumen tidak akan berpikir panjang untuk membeli produk".

Produk makanan CV. Cemilan Kunik merupakan salah satu perusahaan perorangan yang bergerak dibidang usaha makan online. Adapun produk-produk yang dipasarkan oleh Cemilan Kunik meliputi : banarolla atau banana roll terdiri dari beberapa varian yaitu (fudgy brownies, choconuts, double choco, greentea almond, choco milky oreo, banabites), ciomy, kepo chips (keripik pisang), nasuwa (nasi uduk warna), mr.pooe (kripik peyeum), casuga (caramel susu), halia cookies, d'tella hot (keripik cireng), abonda (abon ikan peda), boncu (abon cubit), jitrex kue bawang Garut, candied mango (manisan kering buah), habbats drink (minuman serbuk jahe). Lalu ada juga produk dapur para ibu dengan nama produk sahabat ibu yaitu garam kristal himalaya, halawa (MSG organik), albariyu (madu hutan), dll yang ditawarkan dan dipasarkan melalui online.

Dalam upaya meningkatkan daya Tarik konsumen, produk makanan CV. Cemilan Kunik mengusung slogan "Keep Happy, Healty, Halal" dengan artian mengkonsumsi makanan yang sehat, halal dan bahagia. Terbukti cemilan kunik sangat menjaga produk-produk yang dipasarkan dengan bahan yang alami dan tidak menambahkan tambahan bahan pengawet kedalam produknya, meskipun kebanyakan produk diproduksi oleh supplier tetapi ada kesepakatan produksi barang agar tidak menggunakan bahan kimia atau tambahan pengawet.

Rendahnya minat konsumen terhadap produk makanan CV Cemilan Kunik dapat dilihat dari tingkat penjualannya. Dengan menurunnya tingkat penjualan terhadap produk ini maka akan berdampak pada kepada keputusan pembelian konsumen yang ikut menurun. Faktor utama yang menyebabkan keputusan pembelian terhadap produk makanan CV Cemilan Kunik cenderung menurun adalah kualitas produk yang kurang atau kemasan yang kurang baik, serta produk yang kebanyakan dijual dikota-kota lain karena untuk produk makanan CV Cemilan Kunik di Garut kurang banyak diminati disebabkan produk makanan yang tidak asing lagi yang bahkan biasa dibuat oleh ibu-ibu di rumah.
Berikut ini merupakan data penjualan 9 produk makanan CV. Cemilan Kunik Garut.

\section{Tabel 1}

Data Penjualan Produk Makanan CV Cemilan Kunik periode 2014 - 2018

\begin{tabular}{|l|l|l|c|c|c|}
\hline Nama Produk & $\begin{array}{c}\text { Tahun } \\
2014 / \mathrm{pcs}\end{array}$ & $\begin{array}{c}\text { Tahun } \\
2015 / \mathrm{pcs}\end{array}$ & $\begin{array}{c}\text { Tahun } \\
2016 / \mathrm{pcs}\end{array}$ & $\begin{array}{c}\text { Tahun } \\
2017 / \mathrm{pcs}\end{array}$ & $\begin{array}{c}\text { Tahun } \\
2018 / \mathrm{pcs}\end{array}$ \\
\hline Ciomy & 201211 & 210011 & 210021 & 291253 & 251204 \\
\hline Kepo Chips & 2400 & 1089 & 3890 & 6765 & 8412 \\
\hline D'tella Hott & 1200 & 2000 & 1103 & 5098 & 7860 \\
\hline Banabites & 1901 & 2102 & 2009 & 4765 & 5964 \\
\hline $\begin{array}{l}\text { Gift Petit } \\
\text { Deluxe }\end{array}$ & 1224 & 1235 & 2456 & 2311 & 5268 \\
\hline $\begin{array}{l}\text { Gift Box } \\
\text { Deluxe } \\
\text { Mix/12pcs }\end{array}$ & 12528 & 12000 & 12408 & 37188 & 1128 \\
\hline Halawa & 1176 & 1765 & 2098 & 4789 & 4212 \\
\hline $\begin{array}{l}\text { Candied } \\
\text { Mango }\end{array}$ & 1098 & 2903 & 1875 & 3102 & 2592 \\
\hline $\begin{array}{l}\text { Promo } \\
\text { pendaftaran } \\
\text { CEP }\end{array}$ & 300 & 345 & 400 & 378 & 689 \\
\hline (reseller) & & 233450 & 236260 & 355649 & 287329 \\
\hline TOTAL & 223038 & & & & \\
\hline
\end{tabular}

Sumber :Produk Makanan CV Cemilan Kunik 2019

Berdasarkan tabel 1.1 diatas dapat diketahui bahwa jumlah produk yang terjual dari setiap tahun berfluktuasi, Hal ini dapat dilihat pada penjualan yang mengalami peningkatan, akan tetapi disisi lain juga mengalami penurunan. Bisa dilihat pada tahun 2014 target penjualan yang tercapai sebanyak 223038pcs, kemudian pada tahun 2015 target penjualan meningkat sebanyak 233450pcs, dan di tahun 2016 target penjualan sedikit mengalami kenaikan dengan total penjualan sebanyak 236260pcs, selanjutnya pada tahun 2017 mengalami kenaikan yang cukup tinggi dengan total penjualan sebanyak 355649pcs, Namun di tahun 2018 penjualan produk sedikit mengalami penurunan yaitu sebanyak 287329pcs. Maka dari data tersebut dapat disimpulkan bahwa peningkatan penjualan paling tinggi terjadi pada tahun 2017 yaitu sebanyak 355649pcs.

Dalam wawancara awal dengan pihak produk makanan $\mathrm{CV}$ Cemilan Kunik menyebutkan hal yang mendasari terjadinya fluktuasi penjualan dari produk makanan CV Cemilan kunik disebabkan karena banyaknya pesaing sejenis dalam usaha makanan online, tidak tahan lamanya produk dan kemasan yang kurang rapih, iklan yang belum menjangkau masyarakat luas, ketersediaan/stok barang yang kurang, serta beberapa dari bagian produk yang sudah tidak asing lagi bagi warga Garut karena merupakan produk rumahan yang biasa dibuat oleh kebanyakan ibu-ibu.

Berdasarkan hasil observasi dan 
wawancara pendahuluan dengan konsumen yang pernah membeli produk makanan CV Cemilan Kunik melalui penyebaran kuesioner sebanyak 30 orang. Dari hasik observasi awal dapat menggambarkan bahwa keputusan pembelian konsumen terhadap produk makanan CV Cemilan Kunik masih rendah, hal ini terlihat dari tanggapan konsumen bahwa mereka masih merasa keputusan pembelian kurang menarik perhatian para calon konsumen sebelum mereka memutuskan untuk membeli, seperti produk yang ditawarkan diproduksi dengan bahan yang alami tanpa pengawet atau tambahan kimia sehingga tidak dapat bertahan lama atau cepat basi dan membuat konsumen berpindah pada produk lain. Iklan yang kurang menjangkau masyarakat luas sehingga banyak orang atau konsumen yang lebih mengetahui produk makanan CV Cemilan Kunik dari orang lain/masyarakat sekitar ketimbang mengetahui secara pribadi.

Maka dari itu rendahnya keputusan pembelian disebabkan oleh iklan yang belum menjangkau masyarakat luas, tidak tahan lamanya produk atau cepat basi, serta kemasan yang kurang rapih, hal seperti ini tidak sesuai dengan apa yang diharapkan konsumen dan membuat konsumen tidak melakukan pembelian lagi dan memilih untuk membeli pada produk lain. Oleh karena itu, untuk dapat menarik konsumen dan dapat bersaing dengan perusahaan makanan online lainnya, maka hal yang dapat dilakukan adalah memenuhi kebutuhan dan keinginan konsumen sehingga konsumen mencapai kepuasan dengan cara memberikan produk yang berkualitas, iklan yang menarik serta harga yang sesuai dengan daya beli masyarakat sehingga akan mempengaruhi keputusan pembelian konsumen.

Berdasarkan latar belakang penelitian diatas, maka penulis mengambil judul sebagai berikut : "Pengaruh Iklan dan Kualitas Produk Terhadap Keputusan Pembelian (Studi pada Produk Makanan CV. Cemilan Kunik Garut)".

\section{KAJIAN PUSTAKA DAN PEGEMBANGAN HIPOTESIS Iklan}

Beberapa pengertian iklan menurut para ahli, yaitu : Menurut Kasali (2013:81) iklan adalah sebuah pesan yang menawarkan suatu produk yang ditujukan kepada masyarakat melalui media. Sedangkan menurut Ralph S dalam Morissaan, MA (2010:17) iklan adalah segala bentuk komunikasi non personal tentang suatu organisasi, produk, servis, atau ide yang dibayar oleh sponsor tertentu. Kemudian menurut Sandra Moriarty, Nancy Mitchell, dan William Wells (2011:6) iklan adalah jenis komunikasi pemasaran yang merupakan istilah umum yang mengacu kepada semua bentuk teknik komunikasi yang digunakan pemasar untuk menjangkau dan menyampaikan pesan kepada konsumennya.

Dari pemaparan para ahli mengenai iklan diatas, maka dapat disimpulkan bahwa Iklan adalah komunikasi persuasif dengan memanfaatkan media masa dan media interaktif untuk mencapai target audiens yang luas dalam rangka menyampaikan pesan dari pengiklan kepada konsumen.

\section{Dimensi Dan Indikator Iklan}

a. Attention (Perhatian)

Mengandung daya tarik, iklan harus menarik perhatian khalayak sasarannya, hal yang perlu diperhatikan adalah perhatian calon pembeli diklaim, karena hanya iklan yang mampu menarik perhatian sajalah yang akan dibaca atau didengar oleh calon pembeli

b. Interest (Minat)

Mengandung perhatian dan minat, iklan harus bisa membuat orang yang sudah memperhatikan menjadi berminat dan ingin tahu lebih lanjut. Untuk itu mereka dirangsang agar membaca dan mengikuti pesan-pesan yang disampaikan. Dengan demikian penggunaan kata-kata atau kalimat pembuka sebaiknya dapat merangsang orang untuk ingin tahu lebih lanjut.

c. Desire (Keinginan)

Memunculkan keinginan untuk mencoba atau memiliki. Iklan harus berhasil menggerakan keinginan orang untuk memiliki atau menikmati produk yang diiklankan. Kebutuhan atau keinginan mereka untuk memiliki, memakai atau melakukan sesuatu harus dibangkitkan.

d. Conviction (Rasa Percaya)

Menimbulkan keyakinan terhadap produk, untuk menimbulkan rasa percaya pada calon pembeli, sebuah iklan dapat ditunjang dengan berbagai kegiatan peragaan seperti pembuktian, membagi bagikan contoh secara gratis, menyampaikan pandanganpandangan positif dari tokoh masyarakat terkemuka (testimonial) serta hasil pengujian oleh pihak ketiga misalnya dari departemen kesehatan, laboratorium swasta terkenal, atau dari perguruan tinggi.

e. Action (Tindakan)

Upaya terakhir untuk membujuk calon pembeli agar sesegera mungkin melakukan tindakan pembelian atau bagian dari proses itu. Memilih kata yang tepat agar calon 
pembeli melakukan respon sesuai dengan yang diharapkan adalah suatu pekerjaan yang sangat sulit. Harus digunakan kata perintah agar calon pembeli bergerak. Penggunaan kata perintah harus diperkirakan dampak psikologisnya, jangan menyinggung perasaan atau menimbulkan antipasti. Selain kata perintah, penggunaan batas waktu penawaran dan kupon/formulir yang harus diisi bisa merupakan cara untuk menimbulkan tindakan.

\section{Pengertian Kualitas Produk}

Beberapa pengertian kualitas produk menurut para ahli, yaitu : Menurut Kotler (2012:29), "Kualitas produk adalah keseluruhan ciri serta dari suatu produk atau pelayanan pada kemampuan untuk memuaskan kebutuhan yang dinyatakan atau tersirat". Sedangkan Menurut Feingenbaum dalam Marwanto (2015:153) kualitas produk adalah seluruh gabungan karakteristik prooduk dari pemasaran, rekayasa (perencanaan), pembuatan produk dan pemeliharaan yang membuat produk yang digunakan memenuhi harapan-harapan pelanggan. Kemudian menurut Handoko dalam Prajati (2013:16) kualitas produk adalah suatu kondisi dari sebuah barang atau hasil yang menyebabkan barang atau hasil tersebut sesuai dengan tujuan untuk apa barang atau hasil itu dimaksudkan.

Berdasarkan beberapa definisi diatas dapat disimpulkan bahwa kualitas produk adalah kemampuan suatu produk dalam memenuhi keinginan konsumen. Keinginan konsumen tersebut diantaranya daya tahan produk, keandalan produk, kemudahan pemakaian, serta atribut bernilai lainnya yang bebas dari kekurangan dan kerusakan.

\section{Dimensi Dan Indikator Kualitas Produk}

Berikut dimensi kualitas produk menurut Tjiptono (2010:97), antara lain :

a. Kinerja (Performance)

Kinerja merupakan karakteristik atau fungsi utama suatu produk. Manfaat atau khasiat utama produk yang dibeli konsumen, biasanya menjadi pertimbangan pertama konsumen dalam membeli produk. Seperti varian rasa, varian kemasan, dan bentuk kemasan.

b. Ciri-ciri atau keistimewaan tambahan (Features)

Dimensi fitur merupakan karakteristik atau ciri-ciri tambahan yang melengkapi manfaat dasar suatu produk. Fitur bersifat pilihan atau option bagi konsumen, kalau manfaat utama sudah standar, fitur ditambahkan untuk meningkatkan kualitas produk yang tidak dimiliki oleh perusahaan pesaing. Seperti promosi atau cash back.

c. Keandalan (Realibility)

Dimensi keandalan adalah peluang suatu produk bebas dari kegagalan saat menjalankan fungsinya. Seperti ukuran kemasan dan bahan baku.

d. Kesesuaian dengan spesifikasi (Conformance to Specification)

Conformance adalah kesesuaian kinerja produk dengan standar yang dinyatakan suatu produk. Ini semacam janji yang harus dipenuhi oleh produk. Seperti cita rasa produk.

e. Daya tahan (Durability)

Daya tahan menunjukkan usia produk, yaitu jumlah pemakaian suatu produk sebelum produk itu digantikan. Seperti kemasan tidak mudah rusak, ketahanan atau masa kadaluarsa.

f. Kemampuan diperbaiki (Serviceability) Sesuai dengan maknanya, disini kualitas produk ditentukan atas dasar kemampuan diperbaiki, mudah, cepat dan kompeten. Seperti penanganan complain yang memuaskan.

g. Daya tarik produk (Aesthetic)

Tampilan produk, design produk agar lebih menarik untuk konsumen. Seperti aroma, rasa.

h. Kualitas yang dipersepsikan (Perceived Quality)

Ini menyangkut penilaian konsumen terhadap citra dan iklan. Seperti logo kemasan, tampilan kemasan.

\section{Keputusan}

Beberapa pengertian keputusan pembelian menurut para ahli, yaitu : Tjiptono (2014:21) keputusan pembelian adalah sebuah proses dimana konsumen mengenal masalahnya, mencari informasi mengenai produk, atau merek tertentu, dan mengevaluasi sebarapa baik masing-masing alternatif tersebut dapat memecahkan masalahnya, yang kemudian mengarah kepada keputusan pembelian. Kemudian menurut Setiadi (2010:332) keputusan pembelian adalah proses pengintegrasian yang mengkombinasikan pengetahuan untuk mengevaluasi dua atau lebih perilaku alternatif, dan memilih salah satu diantaranya. Sedangkan menurut Buchari Alma (2013:96) keputusan pembelian adalah suatu keputusan yang dipengaruhi oleh ekonomi keuangan, teknologi, politik, budaya, produk, harga, lokasi, promosi, physical evidence, people, dan process. Sehingga membentuk suatu sikap pada konsumen untuk mengolah 
segala informasi dan mengambil kesimpulan berupa respons yang muncul produk apa yang akan dibeli.

Berdasarkan pengertian diatas dapat diartikan bahwa keputusan pembelian merupakan suatu motif yang timbul dari dalam diri seseorang untuk membeli suatu produk barang atau jasa untuk konsumen pribadi.

Dimensi Dan Indikator Keputusan Pembelian Menurut Kotler dan Armstrong (2014:176-178), konsumen akan melewati 5 tahap proses yang akan dilakukan sebagai indikator proses keputusan pembelian. Tahaptahap tersebut diuraikan sebagai berikut :

a. Need recognition (pengenalan kebutuhan), yaitu proses konsumen mengenali sebuah masalah atau kebutuhan.

b. Information search (pencarian informasi), yaitu proses konsumen terdorong untuk mencari informasi yang lebih banyak. Sumber informasi konsumen, seperti : Sumber dari publik (teman atau kerabat), sumber media sosial.

c. Evaluation of alternatives (evaluasi alternatif), yaitu proses konsumen menggunakan informasi untuk mengevaluasi dalam menetapkan pilihan.

d. Purchase decision (keputusan pembelian), yaitu proses konsumen membentuk preferensi atas merek- merek yang ada di dalam tahap evaluasi.

e. Postpurchase behavior (perilaku pasca pembelian), yaitu proses konsumen akan mengalami kepuasan atau ketidakpuasan dengan pembelian yang dilakukan.

Berdasarkan uraian diatas dapat dikonstruksikan model hubungan variabelnya dalam struktur paradigma penelitian ini adalah sebagai berikut:

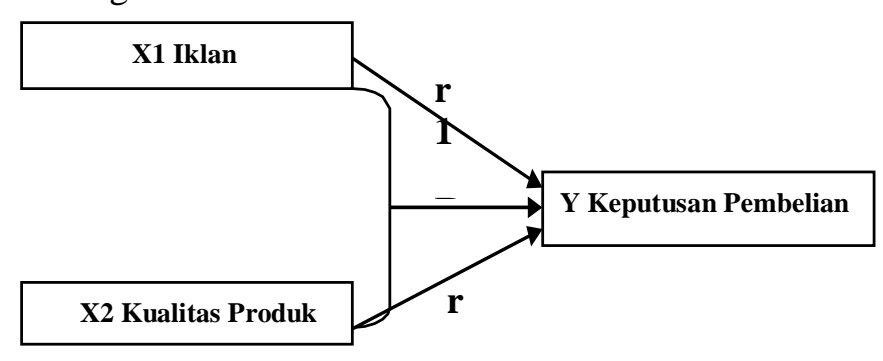

Berdasarkan kerangka pemikiran penelitian, maka hipotesisnya yaitu :

a. Terdapat pengaruh yang positif iklan terhadap keputusan pembelian pada produk makanan CV Cemilan Kunik Garut.

b. Terdapat pengaruh yang positif kualitas produk terhadap keputusan pembelian pada produk makanan CV Cemilan

Kunik Garut.

c. Terdapat pengaruh yang positif iklan dan kualitas produk terhadap keputusan pembelian pada produk makanan $\mathrm{CV}$ Cemilan Kunik Garut.

\section{METODE PENELITIAN}

Metode penelitian yang digunakan dalam penelitian ini adalah menggunakan metode deskriptif Populasi dalam penelitian ini adalah Populasi yang diambil dalam penelitian ini adalah seluruh konsumen yang pernah melakukan pembelian produk pada produk makanan $\mathrm{CV}$ Cemilan Kunik Garut. Karena proporsi tidak diketahui maka peneliti melakukan maximal estimation dengan menetapkan $\mathrm{p}=0,5$, sedangkan persisi ditetapkan $10 \%$ maka ukuran sampel minimal yang dapat diambil adalah sebanyak 68 orang. Teknik analisis data yang digunakan dalam penelitian ini adalah secara kualitatif dan kuantitatif, yaitu data yang diperoleh mengenai objek penelitian dianalisis berdasarkan perbandingan antara teori dengan kenyataan yang diperoleh selama penelitian serta dianalisis dengan menggunakan rumus statistika berupa uji validitas dan uji reliabilitas, analisis koefisien korelasi, koefisien determinasi, dan uji hipotesis.

\section{HASIL PENELITIAN DAN PEMBAHASAN \\ Iklan Pada Produk Makanan CV Cemilan Kunik Garut}

Setelah membuktikan teori-teori yang dijadikan referensi dan melakukan perhitungan sesuai jawaban responden dalam kuesioner iklan, tanggapan responden diketahui tentang iklan berada pada kategori sangat baik. Adapun indikator pada iklan yang mendapat nilai tertinggi yaitu iklan yang di tayangkan sudah menarik, iklan produk makanan CV Cemilan Kunik menciptakan konsumen untuk mengenal produknya secara lebih jauh mengenai makanan alami bebas pengawet, dan iklan pada produk makanan CV Cemilan Kunik dapat memenuhi kebutuhan informasi konsumennya.

\section{Kualitas Produk Pada Produk Makanan CV Cemilan Kunik Garut}

Setelah membuktikan teori-teori yang dijadikan referensi dan melakukan perhitungan sesuai jawaban responden dalam kuesioner kualitas produk, tanggapan responden diketahui tentang kualitas produk berada pada kategori sangat baik. Adapun indikator pada kualitas produk yang mendapat nilai tertinggi yaitu varian rasa yang beragam, varian kemasan yang 
menarik, dan bentuk kemasan sesuai dengan selera konsumen.

\section{Keputusan Pembelian Pada Produk Makanan CV Cemilan Kunik Garut}

Setelah membuktikan teori-teori yang dijadikan referensi dan melakukan perhitungan sesuai jawaban responden dalam kuesioner keputusan pembelian, tanggapan responden diketahui tentang keputusan pembelian berada pada kategori sangat baik. Adapun indikator pada keputusan pembelian yang mendapat nilai tertinggi yaitu konsumen membeli produk makanan CV Cemilan Kunik karena adanya kebutuhan, Konsumen mendapatkan informasi mengenai produk makanan CV Cemilan Kunik melalui media sosial dan evaluasi produk yaitu akan membeli ulang produk makanan CV Cemilan Kunik.

\section{Pengaruh Iklan dan Kualitas Produk}

Terhadap Keputusan Pembelian Produk Makanan CV Cemilan Kunik

Hasil perhitungan dengan menggunakan analisis koefisien korelasi Pearson Product Moment secara bersama-sama (simultan) menggunakan Software SPSS versi 20 diperoleh nilai sebesar 0,842, yang berdasarkan pedoman interpretasi koefisien korelasi menurut Sugiyono (2016:214) berada pada interval koefisien 0,80- 1,000. Sehingga dapat ditafsirkan, bahwa keeratan hubungan antara variabel $\mathrm{X}_{1}$ (Iklan) dan $\mathrm{X}_{2}$ (Kualitas Produk) terhadap variabel $Y$ (Keputusan Pembelian) pada produk makanan CV Cemilan Kunik mempunyai keeratan hubungan yang sangat kuat. Hal ini terlihat dari iklan yang menarik yang membuat konsumen tertarik untuk membeli produk makanan CV Cemilan Kunik, iklan produk alami bebas pengawet yang membuat konsumen ingin tahu lebih jauh, iklan produk yang dapat memenuhi kebutuhan infomasi konsumennya, varian rasa yang beragam sehingga konsumen tertarik untuk mencoba varian rasa yang lain, varian kemasan yang menarik karena memiliki kemasan yang kekinian, dan bentuk kemasan yang sesuai dengan selera konsumen karena disesuaikan dengan isi dan macam makanannya. Keenam hal ini akan mempengaruhi tingkat keputusan pembelian dengan terlihatnya perilaku konsumen yang akan melakukan pembelian kembali produk makanan CV Cemilan Kunik, setiap konsumen akan membeli produk makanan CV Cemilan Kunik ketika sedang membutuhkannya, setiap konsumen akan mendapatkan infomasi atau mencari infomasi melalui media sosial, dan setiap konsumen akan membeli produk makanan CV Cemilan Kunik setelah menilai produknya terlebih dahulu. Sejalan dengan Kotler, (2012 :212) bahwa pemasar harus memperhatikan kualitas, bahkan diperkuat dengan periklanan dan harga yang wajar maka konsumen tidak akan berpikir panjang untuk melakukan pembelian terhadap produk.

Uji determinasi yang dilakukan untuk mengetahui besarnya konstribusi Iklan (X1) dan Kualitas Produk (X2) Terhadap Keputusan Pembelian (Y), diperoleh koefisien determinasi sebesar 67,9\%. Dari hasil tersebut, dapat diinterpretasikan bahwa besarnya kontribusi pengaruh iklan (variabel X1) dan kualitas produk (variabel X2) terhadap keputusan pembelian (variabel Y) adalah sebesar 67,9\% dan sisanya sebesar $32,1 \%$ dipengaruhi oleh faktor-faktor lain yang tidak diteliti dalam penelitian ini.

\section{KESIMPULAN DAN SARAN}

Penelitian ini bertujuan untuk mengetahui pengaruh variabel Iklan dan Kualitas Produk Terhadap Keputusan Pembelian pada produk makanan CV Cemilan Kunik. Berdasarkan rumusan masalah penelitian yang diajukan, serta berdasarkan analisis data yang telah dilakukan dan pembahasan yang telah dikemukakan pada bab sebelumnya, maka dapat ditarik beberapa kesimpulan dari penelitian ini yaitu sebagai berikut :

a. Iklan yang digunakan pada produk makanan CV Cemilan Kunik ada pada kategori sangat baik. Hal tersebut terlihat dari indikator iklan pada produk makanan CV Cemilan Kunik yang sudah berjalan baik diantaranya iklan yang di tayangkan sudah menarik, iklan produk makanan CV Cemilan Kunik menciptakan konsumen untuk mengenal produknya secara lebih jauh mengenai makanan alami bebas pengawet, dan iklan pada produk makanan CV Cemilan Kunik dapat memenuhi kebutuhan informasi konsumennya. Namun demikian ada indikator yang belum berjalan dengan optimal yaitu adanya iklan testimoni konsumen lebih yakin untuk mengkonsumsi produk.

b. Kualitas Produk makanan CV Cemilan Kunik ada pada kategori sangat baik. Hal tersebut terlihat dari indikator kualitas produk makanan CV Cemilan Kunik yang sudah berjalan baik diantaranya produk makanan CV Cemilan Kunik memiliki varian rasa yang beragam, produk makanan CV Cemilan Kunik memiliki varian kemasan yang menarik, dan bentuk kemasan produk 
makanan CV Cemilan Kunik sesuai dengan selera konsumen. Namun demikian ada indikator yang belum berjalan dengan optimal yaitu produk makanan mempunyai ketahanan dan masa kadaluarsa yang cukup lama.

c. Keputusan Pembelian produk makanan CV Cemilan Kunik ada pada kategori sangat baik, hal tersebut terlihat dari indikator keputusan pembelian pada produk makanan CV Cemilan Kunik yang sudah berjalan baik, diantaranya konsumen memutuskan membeli produk makanan CV Cemilan Kunik karena adanya kebutuhan, konsumen mengetahui produk makanan CV Cemilan Kunik karena informasi dari media sosial, dan konsumen akan membeli ulang produk makanan CV Cemilan Kunik karena telah menilai produknya terlebih dahulu. Namun demikian ada indikator yang belum berjalan dengan optimal yaitu memutuskan untuk membeli.

d. Pengaruh Iklan Terhadap Keputusan Pembelian dapat dibuktikan melalui hasil pengujian dan analisis statistik dengan menggunakan uji koefisien korelasi Rank Spearmen dan uji determinasi. Berdasarkan hasil perhitungan koefisien korelasi Rank Spearmen, maka dapat diketahui bahwa hubungan antara iklan terhadap keputusan pembelian pada produk makanan $\mathrm{CV}$ Cemilan Kunik mempunyai hubungan yang "kuat". Koefisien determinasi pengaruh iklan terhadap keputusan pembelian pada produk makanan CV Cemilan Kunik sebesar 41,3\% dan sisanya $58,7 \%$ dipengaruhi oleh faktorfaktor lain yang tidak diteliti dalam penelitian ini.

e. Pengaruh Kualitas Produk Terhadap Keputusan Pembelian pada produk makanan CV Cemilan Kunik dapat dibuktikan melalui hasil pengujian dan analisis statistik dengan menggunakan uji koefisien korelasi Rank Spearmen dan uji determinasi. Berdasarkan hasil perhitungan koefisien korelasi Rank Spearmen, maka diketahui bahwa hubungan antara kualitas produk terhadap keputusan pembelian pada produk makanan CVCemilan Kunik mempunyai hubungan yang "kuat". Koefisien determinasi pengaruh kualitas produk terhadap keputusan pembelian pada produk makanan CV Cemilan Kunik sebesar 43,3\%dan sisanya $56,7 \%$ dipengaruhi oleh faktor-faktor lain yang tidak diteliti dalam penelitian ini.

f. Pengaruh Iklan dan Kualitas Produk Terhadap Keputusan Pembelian pada produk makanan CV Cemilan Kunikdapat dibuktikan melalui hasil pengujian dan analisis statistik dengan menggunakan uji koefisien korelasi Product Moment dan uji determinasi. Berdasarkan hasil perhitungan koefien korelasi Product Moment, maka diketahui bahwa hubungan antara iklan dan kualitas produk terhadap keputusan pembelian pada produk makanan $\mathrm{CV}$ Cemilan Kunik mempunyai hubungan yang "sangat kuat". Koefisien determinasi pengaruh iklan dan kualitas produk terhadap keputusan pembelian produk makanan CV Cemilan Kunik sebesar $67,9 \%$ dan sisanya $32,1 \%$ dipengaruhi oleh faktor-faktor lain yang tidak diteliti dalam penelitian ini.

\section{REFERENSI}

Ali, Hasan. 2013. Marketing dan Kasus-Kasus Pilihan. Yogyakarta. CAPS (Center For Academic Publishing Service)

Alma, buchari. 2014. Manajemen Pemasaran dan Pemasaran Jasa CetakanKesembilan. Bandung : Alfabeta

2013. Manajemen Pemasaran dan Pemasaran Jasa. Edisi Revisi. Bandung : Alfabeta Arikunto, Suharsimi. 2014. Prosedur Penelitian Suatu Pendekatan Praktis. Jakarta : RinekaCipta

2008. Prosedur Penelitian Suatu Pendekatan Praktik. Jakarta : Rineka Karya

Assauri, Sofjan. 2008. Manajemen Produksi dan Operasi. Jakarta : Fakultas Ekonomi Universitas Indonesia Baum, Feigan. 2012. Kendali Mutu. Terpadu (Alih Bahasa). Jakarta : Erlangga

Budiasih, Yanti. 2012. Statistik Deskriptif Untuk Ekonomi dan Bisnis. Tangerang : Jelajah Deliyanti, Oentoro. 2012. Manajemen Pemasaran Modern. Yogyakarta : LaksBang. PRESSindo Handoko T, Hani. 2011. Manajemen Personalia dan Sumberdaya Manusia. Yogyakarta : BPFE Hermawan, Agus. 2012. Komunikasi Pemasaran. Jakarta : Erlangga

Husein, Umar. 2011. Metode Penelitian Untuk Skripsi dan Tesis Bisnis Edisi 11. Jakarta : PT Raja Grafindo Persada

Indrawan Rully, dan Poppy Yuniawati. 2014. Metodologi Penelitian. Bandung : PT Refika Aditama Indriyo, Gitosudarmo. 2008. Manajemen Pemasaran. Edisi pertama. Cetakan keempat, Yogyakarta : BPFE Junaedi, Fajar. 2013. Komunikasi Massa Pengantar Teoritis. Yogyakarta : Santusta 
Kotler, Philip dan Amstrong Gary 2008. Prinsipprinsip Pemasaran. Edisi ke-12. Jakarta: Erlangga

2014. Principle of Marketing. $15^{\text {th }}$ Edition, Pearson Education Limited 2016. Prinsip-Prinsip Pemasaran. Edisi 13. Jilid 1. Jakarta : Erlangga Kotler, Philip dan Keller, Kevin Lane. 2009. Manajemen Pemasaran. Jakarta: Erlangga

Kotler, Philip. 2012. Manajemen Pemasaran. Edisi Kedua Belas, Cetakan Ketiga. Jakarta : PT Indeks Laksana, Fajar. 2010. Manajemen Pemasaran Pendekatan Praktis. Yogyakarta : Graha Ilmu

Machfoedz, Mahmud. 2010. Komunikasi Pemasaran Modern. Cetakan Pertama. Yogyakarta : Cakra Ilmu 